\title{
Sustainability Reporting and Firms' Economic Performance: Evidence from Asia and Africa
}

\author{
Alicia Girón ${ }^{1} \cdot$ Amirreza Kazemikhasragh ${ }^{1} \cdot$ Antonella Francesca Cicchiello $^{2}$ (D) \\ Eva Panetti ${ }^{3}$
}

Received: 29 April 2020 / Accepted: 13 September 2020 / Published online: 28 September 2020

(C) The Author(s) 2020

\begin{abstract}
Given the increasing concern for the global environmental issues and the relating need for preservation of the ecosystem, sustainability reporting has become more and more important, to both developed and developing economies, sparking the interest of the literature. This study primarily aims to investigate the factors that influence the adoption of new sustainability reporting practices and external assurance. Also, this paper examines the relationship between the reporting activity and firms' economic performance. The paper combines data from the Global Reporting Initiative's (GRI) Sustainability Disclosure Database and the Orbis database, from Bureau van Dijk. More specifically, the study uses two logit models and one regression model based on a sample of 366 large Asian and African companies which have addressed the SDGs in their sustainability reports published in 2017. The results reveal that operating in the manufacturing sector and having a higher percentage of women directors in the company's management structure are positively related to the adoption of sustainability reporting and external assurance. Also, operating in the manufacturing sector leads to better firms' economic performance. Contrarily from previous studies, the age of the company's board of directors does not have influences on the use of sustainability reporting. This research contributes to the sustainability issues in the context of emerging markets by explaining the driving factors behind it and its linkage with firms' performance.
\end{abstract}

Keywords Sustainability reporting · Sustainable development goals (SDGs) · Board gender diversity $\cdot$ Firm performance

JEL Classification $\mathrm{L} 2 \cdot \mathrm{M} 14 \cdot \mathrm{P} 48 \cdot \mathrm{Q} 01$

Antonella Francesca Cicchiello

antonella.cicchiello@unicatt.it

Extended author information available on the last page of the article 


\section{Introduction}

During the years, sustainability reporting has established itself as a key instrument capable of helping companies and organizations to satisfy the growing demand for transparency from customers, investors, other stakeholders, and from the society in general (Martínez et al. 2016). Through sustainability reports, companies disclose voluntary information about the economic, environmental and social impacts produced by their activities. This allows companies to reduce information asymmetries and increase transparency on their-positive or negative-sustainability performance (Nobanee and Ellili 2016).

Moreover, this increased transparency provides investors with the possibility to make more appropriate valuations and to better orient their investment towards companies with a more positive impact. This translates into better competitive positions (Fracarolli Nunes and Lee Park, 2017) and greater advantages on the market (Milne and Gray, 2013) for companies that, by demonstrating their social commitment, responsibility and sustainability in behaviour, manage to obtain the legitimacy and the social acceptance they need to be successful (Hahn and Kühnen 2013; Scherer et al. 2013; Martínez et al. 2016).

In light of this, companies and organizations are increasingly paying attention to sustainability issues, and in applying more sustainable business models (Morioka et al. 2017) and new strategies for reporting (Clark et al. 2015).

Among the major providers of sustainability reporting guidance, ${ }^{1}$ the Global Reporting Initiative's (GRI's) Sustainability Reporting Standards are the most adopted frameworks for voluntary reporting worldwide (Brown et al. 2009b).

In 2018, the GRI together with the United Nations Global Compact (UNGC) gave life to a collaborative initiative aimed at empowering corporate actions towards achieving the United Nations Sustainable Development Goals (SDGs). The SDGs have been introduced in 2015 by the United Nations Procurement Division (UNDP) as part of the 2030 Agenda for Sustainable Development the aim of which is to provide as a framework for institutions and organizations to work towards a more sustainable world (United Nations General Assembly 2015). They consist of a set of 17 global goals structured into 169 ambitious targets to be reached by 2030 .

The initiative mentioned above has enabled companies to incorporate SDGs into their existing business and reporting processes. Business reporting on the SDGs integrates the GRI Standards and the UN Global Compact Communication on Progress (Global Reporting Initiative 2018).

Contributing to the achievement of the SDGs is crucial for companies to achieve sustainable development goals in different areas (Kuzey and Uyar 2017; Moldavska and Welo 2019), and succeed in the short and long term (Agarwal et al. 2017).

The KPMG (2017) survey based on corporate responsibility (CR) and sustainability reporting from 4900 companies in 49 countries and regions reveals that reporting on SDGs has increased considerably worldwide since their launch. Of the 3543 N100

\footnotetext{
${ }^{1}$ The other main providers of sustainability reporting guidance include (i) The Organization for Economic Co-operation and Development (OECD Guidelines for Multinational Enterprises), (ii) The United Nations Global Compact (UNGC) (the Communication on Progress) and (iii) The International Organization for Standardization (ISO 26000, International Standard for social responsibility).
} 
companies and 233 G250 companies $^{2}$ that report on CR, a large part of the two groups (39\% and $43 \%$, respectively) made a connection between the company's sustainability reporting and the SDGs.

The integration of SDGs in business reports allows companies to show their commitment to addressing global issues related to sustainable development such as poverty, environmental degradation, climatic changes and discrimination (Adams 2017).

Given the increasing concern for the global environmental issues and the relating need for preservation of the ecosystem, sustainability reporting has become more and more important, to both developed and developing economies, sparking the interest of the literature (Hahn and Kühnen 2013). Consequently, an increasing number of scholars has started to analyse the factors influencing the adoption of new sustainability methods in business reporting (Bear et al. 2010; Da Silva Monteiro and Aibar-Guzmán 2010; Gallo and Christensen 2011; Gamerschlag et al. 2011; Arayssi et al. 2016; Ben-Amar et al. 2017; Anazonwu et al. 2018; Dissanayake et al. 2019). Prior studies also have analysed the adoption of external assurance of sustainability reporting in order to increase the transparency of the sustainability information disclosed and enhance stakeholders' confidence (Kolk and Perego 2010; Moroney et al. 2012; Junior et al. 2014; Peters and Romi 2015). Most of these studies provide empirical evidence on the role played by external assurance — made by professional accountants — in enhancing the credibility of sustainability reports (Park and Brorson 2005; Pflugrath et al. 2011). Some authors have examined the relationship between firms' characteristics and the adoption of external assurance, finding that some factors, such as the firm size, the ownership structure, the industrial affiliation, board composition, and so on, play a determinant role in the adoption of external assurance of sustainability reporting (Haddock-Fraser and Fraser 2008; Lourenço and Branco 2013; Sierra et al. 2013; Branco et al. 2014; Amran et al. 2014; Shamil et al. 2014; De Beelde and Tuybens 2015).

Finally, a limited number of existing studies have analysed the sustainability reporting and its impact on firm performance (Ameer and Othman 2012; Bachoo et al. 2013), and evaluation (Lo and Sheu 2007; Schadewitz and Niskala 2010; Berthelot et al. 2012).

However, much of the literature on sustainability reporting mainly focuses on the quality of the different institutional environments and the pressure exerted by stakeholders on companies (Michelon and Parbonetti 2012; Klettner et al. 2014). Consequently, the influence of organizational factors, such as the organizations' internal structure, decision-making, performance, or governance structure, is often overlooked and needs to be dealt with more comprehensively (Hahn and Kühnen 2013; Sarbah and Xiao 2015).

Moreover, prior studies have principally focused on developed countries (especially on Europe and the USA) (Lo and Sheu 2007; Berthelot et al. 2012) leaving the topic partly unexplored in relation to developing countries (Kuzey and Uyar 2017).

The contribution of this research is threefold. Firstly, this study extends the literature on sustainability reporting in the emerging market context by examining the influence

\footnotetext{
${ }^{2}$ According to the KPMG study, the N100 refers to a worldwide sample of 4900 companies comprising the top 100 companies by revenue in each of the 49 countries researched in the study. While, the G250 refers to the world's 250 largest companies by revenue based on the Fortune 500 ranking of 2016.
} 
of company characteristics on the adoption of new sustainability reporting practices (i.e., SDG reporting). Additionally, it addresses the question of how the gender and age diversity of board resources affects the adoption of the external assurance of sustainability reporting, providing suggestions for further research in the field of assurance of sustainability reporting. Secondly, this study contributes to the existing literature on the relationship between sustainability reporting and firms' economic performance providing evidence from large companies in the low- and middle-income countries in Asia and Africa. Finally, through its empirical findings, this study provides statistical and economical validity to the 2018 joint initiative of the GRI and the United Nations Global Compact (UNGC) aimed at empowering corporate actions towards achieving the United Nations SDGs.

The study employs two logit models and one regression model based on a sample of 366 large Asian and African companies which have addressed the SDGs in their sustainability reports published in 2017.

The rest of this paper is organized as follows. Section 2 discusses the theoretical background on sustainability reporting. Section 3 presents the research setting, data and analysis. Section 4 examines the results of our analyses. Section 5 concludes and discusses the implications of our findings.

\section{Literature Review}

The increasing concern for the global environmental issues it forced companies to worry not only about their financial performance but also about their non-financial performance in order to address the different economic, environmental and social expectations of their stakeholders and obtain the legitimacy they need to succeed (Freeman 1994; Martínez et al. 2016).

Indeed, to obtain the resources they need to carry out their activities, companies have to prove to address societal demands and obtain organizational legitimacy. Social and environmental reporting (SAR) can help companies in managing public pressures (Cormier et al. 2005), and creating and maintaining this legitimacy (Deegan 2002).

The literature on sustainability reporting has widely recognized the positive effect that companies obtain in disclosing information related to the sustainability of their daily activities (Hahn and Kühnen 2013). The disclosure of information related to the companies' sustainability performance reduces information asymmetries and increases transparency (Nobanee and Ellili 2016). This helps investors to make a better assessment and comparison of companies according to the risks and opportunities they face and to make more informed investment choices, directing their capital towards more sustainable objectives.

According to Berthelot, Coulmont and Serret (2012), investors positively value the publication of sustainability reports. Based on a sample of 146 Canadian companies listed on the Toronto Stock Exchange, the authors find empirical evidence that firms publishing sustainability reporting enjoy a better reputation among investors and are therefore treated at a premium.

By signalling their commitment to achieving sustainable goals, companies enhance their reputation, credibility and legitimacy towards internal and external stakeholders (Belal 2002; Herzig and Schaltegger 2006; Calabrese et al. 2015). By analysing the 
market reactions to the first standalone sustainability reports issued by a sample of 59 US companies over the period from 2001 to 2007, Brown et al. (2009a) find evidence that highest quality sustainability reports positively enhance corporate reputations. In a later study, Guidry and Patten (2010) report similar results.

Sustainability reporting could provide companies with the possibility to strengthen their public and social visibility. Reverte (2009) states that media exposure is the most influential variable for explaining CSR disclosure practices of Spanish listed firms.

Moreover, sustainability reporting, by signalling a social and environmental commitment to stakeholders, could help companies to achieve a better competitive position in the market (Cormier et al. 2005; Kiliç and Uyar 2014; Kuzey and Uyar 2017) and even create new competitive advantages (Nor et al. 2016; Ortas et al. 2017; Uwuigbe et al. 2018

According to a limited number of existing studies, this improves company's performance (Ameer and Othman 2012; Bachoo et al. 2013) and its value (Lo and Sheu 2007; Schadewitz and Niskala 2010; Anam et al. 2011; Kuzey and Uyar 2017).

Basing on the signalling theory, Anam et al. (2011) find a positive relationship between sustainability disclosure and firm value linked to an increase in transparency and a consequent reduction in the devaluation of the share price, which in turn increases the firm value.

Similarly, other researchers have provided evidence about the value-enhancing role of sustainability reporting (Lo and Sheu 2007; Schadewitz and Niskala 2010).

In a recent study based on a sample of 297 Turkish publicly traded companies at the Borsa Istanbul, Kuzey and Uyar (2017) find a positive relationship between sustainability reporting and firm value confirming that sustainability reporting is value relevant.

A large part of the literature on sustainability reporting has focused on the factors affecting the adoption of sustainability reporting (Hahn and Kühnen 2013).

Some authors, for example, have proved that the company size (usually measured by the number of employees, total assets, sales or market capitalization) has a positive influence on the decision or the likelihood of a company to engage in sustainability reporting (Janggu et al. 2007; Gallo and Christensen 2011; Das et al. 2015; Schreck and Raithel 2018; Dissanayake et al. 2019). According to these authors, the positive relationship can be explained by the greater public visibility (and pressure) that large companies have to face (Fortanier et al. 2011; Fernando and Pandey 2012; Fernando et al. 2015).

Other authors have analysed the impact of firms' financial, social and environmental performance on sustainability reporting, providing mixed results.

Cormier and Magnan (2003) and Stanny and Ely (2008) find, for instance, a negative relationship between a high level of debt or leverage and sustainability reporting due to the company's inability to bear the costs necessary for reporting. Companies with a high level of profitability can, instead, bear the costs of sustainability reporting and face any negative consequences related to the disclosure of harmful information (Cormier and Magnan 2003; Haniffa and Cooke 2005; Kent and Monem 2008).

Contrarily, Haniffa and Cooke (2005) find that by disclosing sustainability reporting, companies can legitimize their corporate activities towards creditors. 
Authors analysing the influence of social and environmental performance (measured, for example, by the number of fines for environmental transgressions or the data on pollution discharge) provide evidence of a positive effect on sustainability reporting activities (Clarkson et al. 2008). According to Belal and Cooper (2011), companies that enjoy a good social and environmental performance use sustainability reporting to signal it to their stakeholders. On the contrary, companies with poor social and environmental performance show unwillingness to publish reports as they are frightened by bad publicity.

The literature widely recognized the relationship between the industry sector in which companies operate and their engagement in sustainability reporting (Brammer and Pavelin 2006; Clarkson et al. 2011; Alrazi et al. 2016; Kuzey and Uyar 2017).

According to the literature, sectors with high social and environmental impacts (e.g., manufacturing sectors) and sectors with a close relationship to consumers (e.g., banking, food/drink/tobacco, media and retailing) tend to disclose a high rate of information on the environmental impact of their activities through sustainability reports because of the great pressure from stakeholders and the consequent need to prove them their environmental responsibility. Sectors with a lower level of environmental impact and of proximity to consumers (e.g., the IT, construction, telecommunications) show, instead, a lower rate of disclosure and report.

The literature on sustainability reporting also has investigated the relationship between firms' reporting activities and its ownership structure, finding interesting results (Shamil et al. 2014; Kiliç et al. 2015; Jizi 2017; Ortas et al. 2017; Odoemelam and Ofoegbu 2018; Ofoegbu et al. 2018; Rosati and Faria 2019).

State-owned companies provide, for example, more extensive reports (Tagesson et al. 2009; Amran and Haniffa 2011) than publicly listed companies. However, these last disclose higher-quality information (Haniffa and Cooke 2005; Da Silva Monteiro and Aibar-Guzmán 2010; Gamerschlag et al. 2011) and are more engaged in sustainability reporting (Haddock 2005).

Concentrated ownership negatively influences the quality and extent of the sustainability reports (Brammer and Pavelin 2006; Cormier and Magnan 2003; Gamerschlag et al. 2011). While foreign ownership can positively influence the level of sustainability reporting (Cormier and Magnan 2003; Haniffa and Cooke 2005; Othman and Ameer 2009).

By analysing the size of the board of directors, for instance, several studies found a positive influence of its large size on the level of environmental disclosure (Siregar and Bachtiar 2010; Htay et al. 2012; Rao et al. 2012; Andrikopoulos and Kriklani 2013; Raman and Bukair 2013; Jizi et al. 2014; Shamil et al. 2014; Khlif et al. 2015; Osazuwa et al. 2016; Trireksani and Djajadikerta 2016). By analysing the board composition, other studies find that the firms' engagement in sustainability reporting, as well as the quantity and quality of disclosed information, is positively influenced by the presence of independent directors and of a dual leadership structure (Chau and Gray 2010; Zhang 2012; Jizi et al. 2014; Shamil et al. 2014; Liao et al. 2015; Eberhardt-Toth 2017).

By exploring the influence of board gender diversity (measured by the number or the percentage of female directors on the board) on firms' reporting activities, a large number of scholars find evidence of a positive relationship in both developed and 
developing countries (Bear et al. 2010; Post et al. 2011; Liao et al. 2015; Jizi 2017; Ben-Amar et al. 2017; Rosati and Faria 2019).

By analysing companies from the UK, some authors find that boards with higher female participation show a greater propensity in disclosing sustainability information and greater reporting efficiency (Liao et al. 2015; Arayssi et al. 2016; Jizi 2017).

Kiliç et al. (2015) and Anazonwu et al. (2018) find similar results in the Turkish banking industry and in Nigeria, respectively. In a recent study based on a sample of 408 organizations worldwide, Rosati and Faria (2019) show a positive relationship between a high share of female directors and the early adoption of SDG reporting.

In addition to the above-mentioned factors, the literature has recognized that the adoption of external assurance - made by professional accountants - can enhance the credibility of sustainability reports and as a consequence increase stakeholders' confidence (Park and Brorson 2005; Kolk and Perego 2010; Pflugrath et al. 2011; Moroney et al. 2012; Junior et al. 2014; Peters and Romi 2015).

The literature has also recognized that the specific firms' characteristics (e.g., firm size, ownership structure, industrial affiliation and board composition) can influence the adoption of external assurance (Lourenço and Branco 2013; Sierra et al. 2013; Branco et al. 2014; Amran et al. 2014; Shamil et al. 2014; De Beelde and Tuybens 2015).

Although there are numerous studies on sustainability reporting, these are mainly concentrated on the quality of the different institutional environments and the pressure exerted by stakeholders on companies (Michelon and Parbonetti 2012; Klettner et al. 2014).

Moreover, most of these focused on developed countries (especially on Europe and the USA) (Lo and Sheu 2007; Berthelot et al. 2012) leaving the topic partly unexplored in relation to developing countries (Kuzey and Uyar 2017).

Consequently, the influence of organizational factors on sustainability reporting needs to be dealt with more comprehensively (Hahn and Kühnen 2013; Sarbah and Xiao 2015).

Thus, consistent with the previous literature review and its findings, this study aims at extending the literature on sustainability reporting in the emerging market context providing evidence from large companies in the low- and middle-income countries in Asia and Africa.

Specifically, this study explores the following research questions:

RQ1 Do firms' characteristics have a significant positive association with the firm's decision or likelihood to adopt sustainability reporting and external assurance?

RQ2 Does sustainability reporting have a significant positive association with the firm's economic performance?

In order to answer these questions, the paper investigates the influence of company characteristics on the adoption of new sustainability reporting practices (i.e., SDG reporting) and external assurance statements, and analyses the relationship between sustainability reporting and the firms' economic performance. 


\section{Data and Methodology}

\section{Data Sources and Sample}

This study use data collected from GRI's Sustainability Disclosure Database and the Orbis database, from Bureau van Dijk (BVD). The GRI (Global Reporting Initiative) database displays organizations that have published a sustainability/integrated report, indicating for each of them the presence of any explicit reference to the UN SDGs.

From the GRI database, we extracted an initial sample of 369 large organizations in low- and middle-income countries in Asia and Africa which have published a sustainability report following the G4 Sustainability Reporting Guidelines (G4 Guidelines) ${ }^{3}$ in the year 2017. For each organization in the sample, we have collected data relating to its name, the sector, the originating country, and type (e.g., private or not a private company ${ }^{4}$ ).

Moreover, we have collected information on the explicit reference to or the application in the sustainability reports of the following standards and principles:

- the IFC Performance Standards.

- the UNGC (United Nations Global Compact) and its principles.

- the ISO 26000 clauses.

- one of the annual Carbon Disclosure Project (CDP) questionnaires, or an associated CDP project.

- the UN Sustainable Development Goals (SDGs).

- the AccountAbility AA1000 Assurance Standard (AA1000AS).

- the adoption of external assurance, including information related to the type of assurance provider, assurance scope, level of assurance, and assurance standards (i.e., AA1000AS, ISAE3000, national general, and national sustainability).

By entering the names of the 369 organizations in the Orbis database, we obtained the final sample of 366 observations for each of which we have gathered the following information:

- Information about the organizations' economic and financial performance, including the total assets, market capitalisation, taxation, operation revenue, ROE, ROA, EBITDA, Tobin's $q$, leverage and profit margins.

- Information about organizations' corporate governance, including the number of employees, the number of men and women at the management level and the average age of the board of directors.

\footnotetext{
${ }_{3}^{3}$ According to Global Reporting Initiative (2013), "The guidance in G4 is designed to be compatible with a range of different reporting formats". In addition to enhancing the relevance and quality of standalone sustainability reports, G4 also offers a widely recognized global standard for sustainability information to be included in integrated reports"

${ }^{4}$ Non-private companies include (i) state-owned companies (legal entities created by the government to undertake commercial activities on the government's behalf); (ii) cooperatives (organizations jointly owned and democratically controlled by the employees and/or end-users of the goods and services produced to meet their common needs); (iii) subsidiaries (companies controlled by another company through the ownership of $50 \%$ or more of the voting stock); (iv) public institutions (administrative units of government; (v) and partnerships (formation of businesses and/or individuals to advance their business interests).
} 
Table 1 shows the characteristics of the sample by region, country and sector.

\section{Variables}

In line with previous studies (Kuzey and Uyar 2017), this paper examines three hypotheses:

1. The relationship between the company characteristics and the likelihood of address the SDGs in its sustainability report.

2. The relationship between the company characteristics and the adoption of external assurance statements in the company's sustainability report.

3. The relationship between sustainability reporting and firm's economic performance.

For this purpose, we use three dependent variables: (i) "SDGs", a dichotomous variable denoting 1 for companies addressing the UN sustainable development goals (SDGs) in their sustainability report, and 0 otherwise; (ii) "external assurance", a dichotomous variable denoting 1 for companies addressing the external assurance statement in their sustainability report, and 0 otherwise; and (iii) "Tobin's $q$ ", the ratio between a physical asset's market value and its replacement value. As independent variables, we employ a number of financial and economic measures of the companies performances, such as the total assets (ASSET), number of employees (EMP), market capitalization (CAP), taxation (TAX), the earnings before interest, taxes, depreciation and amortization (EBITDA), profit margins (PM), the ratio between a physical asset's market value and its replacement value (TOBQ), leverage (LEV), return on equity (ROE) and return on assets (ROA). We also include a variable indicating the manufacturing or service sector (SEC) and whether the organization is private or not (TYPE).

Finally, following previous studies (Bear et al. 2010; Liao et al. 2015; Jizi 2017; Ben-Amar et al. 2017; Rosati and Faria 2019), we also consider the percentage of the female on the board of the company (FEMALE). Moreover, we include the average age of the members of the board of directors (AGE), expecting that presence of younger directors has a positive influence on the adoption of the SDG practices since younger individuals tend to be more sensitive to environmental issues (Post et al. 2011).

Data sources and variables are presented in Table 2.

\section{Method of Analysis}

We used the following three models for review. To investigate whether the decision or likelihood of an organization to address the SDGs in its sustainability report is related to the factors mentioned above (corporate governance such as gender at the management level and the average age of members of $\mathrm{BoD}$, economic and financial competencies, and so on), we employ a logit model (Rosati and Faria 2019) where our dependent variable is "SDGs" - a binary variable taking value 1 when the organization has addressed the UN sustainable development goals (SDGs) in its sustainability report, and 0 otherwise. The second variable in the model is "external assurance" statement, a dummy variable taking value 1 when company reports are verified by an external 
Table 1 Characteristics of the sample

\begin{tabular}{ll}
\hline Region & $\mathrm{N}(\%)$ \\
\hline Asia & $316(86)$ \\
Africa & $50(14)$ \\
Country & \\
Bangladesh & $4(1.09)$ \\
Cambodia & $1(0.27)$ \\
Cote d'Ivoire & $2(0.55)$ \\
Egypt & $3(0.82)$ \\
India & $39(10.66)$ \\
Indonesia & $42(11.48)$ \\
Kenya & $1(0.27)$ \\
Madagascar & $1(0.27)$ \\
Mainland China & $68(18.58)$ \\
Malaysia & $15(4.1)$ \\
Marocco & $1(0.27)$ \\
Nigeria & $5(1.37)$ \\
Pakistan & $4(1.09)$ \\
Philippines & $11(3.01)$ \\
South Africa & $33(9.02)$ \\
Sri Lanka & $39(10.66)$ \\
Thailand & $3(0.82)$ \\
Turkey &
\end{tabular}


Table 1 (continued)

\begin{tabular}{ll}
\hline Region & $\mathrm{N}(\%)$ \\
\hline Household and personal products & $1(0.27)$ \\
Logistics & $8(2.19)$ \\
Media & $3(0.82)$ \\
Metal products & $8(2.19)$ \\
Mining & $23(6.28)$ \\
Other & $24(6.56)$ \\
Public agency & $1(0.27)$ \\
Railroad & $1(0.27)$ \\
Real estate & $10(2.73)$ \\
Retailers & $5(1.37)$ \\
Technology hardware & $3(0.82)$ \\
Telecommunications & $23(6.28)$ \\
Textiles and apparel & $12(3.28)$ \\
Tobacco & $1(0.27)$ \\
Tourism/leisure & $1(0.27)$ \\
Waste management & $1(0.27)$ \\
Water utilities & $4(1.09)$ \\
Total & $366(100)$ \\
\hline
\end{tabular}

assurance, and 0 otherwise. The third variable in the model is Tobin's $q$, used as a proxy for firm's performance.

The proposed model is given as

$$
\text { SDGs }=\left\{\begin{array}{c}
1 \text { if } \beta_{0}+\beta_{1}(\text { eper })+\beta_{2}(\text { tobq })+\beta_{3}(\text { exter })+\beta_{4}(\text { gov })+\varepsilon \\
0 \text { otherwise }
\end{array}\right.
$$

\section{EXTERNALASSU}

$$
=\left\{\begin{array}{c}
1 \text { if } \beta_{0}+\beta_{1}(\text { eper })+\beta_{2}(\text { tobq })+\beta_{3}(\text { exter })+\beta_{4}(\text { gov })+\varepsilon \\
0 \text { otherwise }
\end{array}\right.
$$

$$
\mathrm{TOBQ}=\left\{\begin{array}{c}
1 \text { if } \beta_{0}+\beta_{1}(\text { eper })+\beta_{2}(\text { tobq })+\beta_{3}(\text { exter })+\beta_{4}(\text { gov })+\varepsilon \\
0 \text { otherwise }
\end{array}\right.
$$

The variable "eper" represents the financial performance of organizations measured by ROE, ROA, leverage and profit margin. The "tobq" variable represents the level of economic performance. To represent external assurance, we use the variable "exter" as 
Table 2 Description of variables and data sources

\begin{tabular}{|c|c|c|c|}
\hline Variable & Symbol & Description & $\begin{array}{l}\text { Data } \\
\text { sources }\end{array}$ \\
\hline \multicolumn{4}{|l|}{ Dependent variable } \\
\hline SDGs & SDG & $\begin{array}{l}\text { Dummy variable equals to } 1 \text { if } \\
\text { company reports with addressing } \\
\text { SDGs, and } 0 \text { otherwise. }\end{array}$ & GRI \\
\hline $\begin{array}{l}\text { External assurance } \\
\text { statement }\end{array}$ & EXTERNALASSURANCE & $\begin{array}{l}\text { Dummy variable equals to } 1 \text { whether } \\
\text { company reports verified by an } \\
\text { external assurance, and } 0 \text { otherwise. }\end{array}$ & GRI \\
\hline Tobin's $q$ & TOBQ & Market capitalisation/total assets. & Orbis \\
\hline \multicolumn{4}{|l|}{ Explanatory variables } \\
\hline Employees & EMP & Number of employees. & Orbis \\
\hline Asset & ASSET & Total assets. & Orbis \\
\hline Capitalisation & CAP & Market capitalisation. & Orbis \\
\hline Taxation & TAX & Taxation. & Orbis \\
\hline Ebitda & EBITDA & $\begin{array}{l}\text { Earnings before interest, taxes, } \\
\text { depreciation, and amortization. }\end{array}$ & Orbis \\
\hline Profit margins & PM & Profit margins. & Orbis \\
\hline ROE & ROE & Return on equity. & Orbis \\
\hline ROA & ROA & Return on assets. & Orbis \\
\hline Sector & SEC & $\begin{array}{l}\text { Dummy variable equals to } 1 \text { whether } \\
\text { company is in the manufacturing sector, } \\
\text { and } 0 \text { otherwise. }\end{array}$ & GRI \\
\hline Type of company & TYPE & Private company or not. & GRI \\
\hline Leverage & LEV & The ratio of total liabilities to total assets. & Orbis \\
\hline Female & FEMALE & Percentage of female members on BoD. & Orbis \\
\hline Age & $A G E$ & The average age of members of BoD. & Orbis \\
\hline
\end{tabular}

the commitment to external stability and assurance. Finally, the variable "gov", used as a feature of the company's structure, represents the gender diversity at the management level measured by the number of women in the board of directors and the average and the sector. We run two logit models when dependent variables are SDGs and EXTERNALASSU and one regression model when the dependent variable is TOBQ.

Table 3 reports the summary statistics. In particular, $71 \%$ of the organizations in the model are private companies. Only $32 \%$ used SDGs guidelines, and $36 \%$ of organizations used external assurance. Moreover, $56.2 \%$ of the firms in the sample operate in the manufacturing sector, while $43.8 \%$ operate in the service sector.

\section{Results}

In this section, we look at the results and findings to explain the relationship between dependent variables and organizational factors (see Table 4). We specifically examine the results of our hypotheses: economic performance, external assurance and the 
Table 3 Summary statistics

\begin{tabular}{llllll}
\hline Variable obs. & Number & Mean & Std. dev. & Min & Max \\
\hline SDGs & 366 & 0.327869 & 0.470079 & 0 & 1 \\
EXTERNALAS & 366 & 0.363388 & 0.481634 & 0 & 1 \\
TOBQ & 268 & 0.801791 & 1.504502 & 0 & 15.52 \\
EMP & 243 & $27,081.65$ & $62,661.88$ & 3 & 449,296 \\
ASSET & 257 & $3,810,426$ & $1.41 \mathrm{E}+07$ & 24.81 & $1.99 \mathrm{E}+08$ \\
CAP & 268 & 6933.292 & $18,419.16$ & 2.35 & $208,120.3$ \\
TAX & 247 & $111,637.9$ & $305,201.7$ & $-516,327$ & $2,398,744$ \\
EBITDA & 221 & $812,117.7$ & $1,957,500$ & $-131,332$ & $1.46 \mathrm{E}+07$ \\
PM & 326 & 15.75015 & 19.79561 & -84.71 & 90.75 \\
ROE & 328 & 17.15576 & 44.15562 & -337.94 & 512.68 \\
ROA & 329 & 4.243161 & 6.832613 & -13 & 60 \\
SEC & 365 & 0.561643 & 0.496866 & 0 & 1 \\
TYPE & 366 & 0.704918 & 0.456704 & 0 & 1 \\
LEV & 108 & 1.040556 & 0.9755352 & 0 & 5.84 \\
FEMALE & 366 & 0.14987 & 0.110712 & 0 & 1 \\
AGE & 352 & 58.42898 & 5.783419 & 41 & 71 \\
\hline
\end{tabular}

characteristics of corporate governance. We used a model for each of these hypotheses. The three models look to find the relationship between all variables and the dependent variables. Our findings show that taxation, asset and profit margin have a significant impact on the SDGs and economic performance (Tobin's $q$ ). The financial performance can be due to the use of high technology or smart marketing by these companies that leads to higher commitment and sustainable development. Economic performance is also important; there is a direct relationship between ROA and Tobin's $q$. These results confirm several studies in the prior literature (see, for example, Khan 2010; Cohen et al. 2012; Sharif and Rashid 2014). In line with Kuzey and Uyar (2017), the results show that operating in the manufacturing sector has a significant positive association with the company's decision to report by addressing SDGs frameworks, and to adopt external assurance statements. Also, operating in the manufacturing sector leads to a high level of Tobin's $q$.

The results on the capital and leverage show a significant and mixed relationship with our dependent variables. Finally, regarding the management structure of companies, there is a direct relationship between gender diversity and SDGs.

In line with previous researches (Lückerath-Rovers 2013; Setó-Pamies 2015), this study shows that having a higher percentage of women directors in the company's management structure is positively related to the adoption of the SDG reporting. This means that gender diversity on the board is a determinant of SDG adoption by large organizations in the low- and middle-income countries in Asia and Africa. Contrarily from previous studies, the age of the company's board of directors does not have influences on the use of sustainability reporting. 
Table 4 Results of statistical analysis

\begin{tabular}{|c|c|c|c|}
\hline Variable & Model 1 & Model 2 & Model 3 \\
\hline Dependent variable & SDGs & EXTERNALAS & TOBQ \\
\hline \multirow[t]{2}{*}{ PM } & $0.05^{* *}$ & -0.11 & $-0.02 * *$ \\
\hline & $(0.04)$ & $(0.07)$ & $(0.01)$ \\
\hline \multirow[t]{2}{*}{ SEC } & $0.63^{*}$ & $0.82 *$ & $0.41^{*}$ \\
\hline & $(0.28)$ & $(1.02)$ & $(0.27)$ \\
\hline \multirow[t]{2}{*}{ ASSET } & $0.35 * *$ & 0.03 & $0.15^{*}$ \\
\hline & $(0.14)$ & $(0.22)$ & $(0.15)$ \\
\hline \multirow[t]{2}{*}{ EBITDA } & -0.001 & -0.001 & 0.001 \\
\hline & $(0.01)$ & $(0.01)$ & $(0.01)$ \\
\hline \multirow[t]{2}{*}{ EMP } & $-0.001 *$ & -0.001 & 0.01 \\
\hline & $(0.01)$ & $(0.01)$ & $(0.01)$ \\
\hline \multirow[t]{2}{*}{ TAX } & $0.01 *$ & 0.00 & $0.01 * *$ \\
\hline & $(0.02)$ & $(0.01)$ & $(0.01)$ \\
\hline \multirow[t]{2}{*}{ ROA } & 0.17 & 0.11 & $0.17 * *$ \\
\hline & $(0.15)$ & $(0.17)$ & $(0.04)$ \\
\hline \multirow[t]{2}{*}{ ROE } & -0.23 & -0.20 & 0.01 \\
\hline & $(0.15)$ & $(0.07)$ & $(0.01)$ \\
\hline \multirow[t]{2}{*}{ LEV } & $-4.94 * *$ & $-0.24 *$ & $-0.25^{* *}$ \\
\hline & $(2.02)$ & $(0.43)$ & $(0.11)$ \\
\hline \multirow[t]{2}{*}{ CAP } & $-0.02 * *$ & 0.01 & $0.001^{* *}$ \\
\hline & $(0.01)$ & $(0.18)$ & $(0.00)$ \\
\hline \multirow[t]{2}{*}{ FEM } & $0.3^{*}$ & 0.48 & $0.05^{*}$ \\
\hline & $(0.16)$ & $(0.19)$ & $(0.14)$ \\
\hline \multirow[t]{2}{*}{ AGE } & 0.01 & 0.01 & 0.01 \\
\hline & $(0.01)$ & $(0.01)$ & $(0.1)$ \\
\hline Pseudo $R^{2}$ & 0.037 & 0.06 & \\
\hline$p$ value & 0.047 & 0.021 & 0.00 \\
\hline
\end{tabular}

Standard errors in parentheses

$* p$ value $<0.1$

$* * p$ value $<0.05$

\section{Discussion and Conclusions}

The research contributes to the growing literature on sustainability reporting in developing economies by examining the influence of company characteristics on sustainability reporting and on the adoption of external assurance statements in the company's sustainability report of large companies in the low- and middle-income countries in Asia and Africa. Moreover, this study contributes to the existing literature by analysing the relationship between sustainability reporting and firms' economic performance. Given the increasing relevance of sustainability reporting, this paper could support large Asian and African companies in increasing their engagement in sustainability 
initiatives by adopting more sustainable long-term strategy and policy. The paper could also support policymakers and other regulators to define impactful frameworks promoting sustainability reporting and the use of external assurance. Finally, the empirical findings of this research contribute to providing statistical and economical validity to the 2018 joint initiative of the GRI and the United Nations Global Compact (UNGC) aimed at empowering corporate actions towards achieving the United Nations SDGs.

Funding Open access funding provided by Università Cattolica del Sacro Cuore within the CRUI-CARE Agreement.

\section{Compliance with Ethical Standards}

Conflict of Interest The authors declare that they have no conflict of interest.

Date Availability Not applicable.

Code Availability Not applicable.

Open Access This article is licensed under a Creative Commons Attribution 4.0 International License, which permits use, sharing, adaptation, distribution and reproduction in any medium or format, as long as you give appropriate credit to the original author(s) and the source, provide a link to the Creative Commons licence, and indicate if changes were made. The images or other third party material in this article are included in the article's Creative Commons licence, unless indicated otherwise in a credit line to the material. If material is not included in the article's Creative Commons licence and your intended use is not permitted by statutory regulation or exceeds the permitted use, you will need to obtain permission directly from the copyright holder. To view a copy of this licence, visit http://creativecommons.org/licenses/by/4.0/.

\section{References}

Adams, C. A. (2017). The sustainable development goals, integrated thinking and the integrated report. Integrated Reporting (IR), 1-52.

Agarwal, N., Gneiting, U., \& Mhlanga, R. (2017). Raising the bar: rethinking the role of business in the sustainable development goals. Oxfam.

Alrazi, B., De Villiers, C., \& Van Staden, C. J. (2016). The environmental disclosures of the electricity generation industry: a global perspective. Accounting and Business Research, 46(6), 665-701.

Ameer, R., \& Othman, R. (2012). Sustainability practices and corporate financial performance: a study based on the top global corporations. Journal of Business Ethics, 108(1), 61-79.

Amran, A., \& Haniffa, R. (2011). Evidence in development of sustainability reporting: a case of a developing country. Business Strategy and the Environment, 20(3), 141-156.

Amran, A., Lee, S. P., \& Devi, S. S. (2014). The influence of governance structure and strategic corporate social responsibility toward sustainability reporting quality. Business Strategy and the Environment, 23 (4), 217-235.

Anam, O. A., Fatima, A. H., \& Majdi, A. R. H. (2011). Effects of intellectual capital information disclosed in annual reports on market capitalization. Journal of Human Resource Costing \& Accounting, 15(2), 85101.

Anazonwu, H. O., Egbunike, F. C., \& Gunardi, A. (2018). Corporate board diversity and sustainability reporting: a study of selected listed manufacturing firms in Nigeria. Indonesian Journal of Sustainability Accounting and Management, 2(1), 65-78.

Andrikopoulos, A., \& Kriklani, N. (2013). Environmental disclosure and financial characteristics of the firm: the case of Denmark. Corporate Social Responsibility and Environmental Management, 20(1), 55-64. 
Arayssi, M., Dah, M., \& Jizi, M. (2016). Women on boards, sustainability reporting and firm performance. Sustainability Accounting, Management and Policy Journal, 7(3), 376-401 Available at: https://assets. $\mathrm{kpmg} /$ content/dam/kpmg/xx/pdf/2017/10/kpmg-survey-of-corporate-responsibility-reporting-2017.pdf.

Bachoo, K., Tan, R., \& Wilson, M. (2013). Firm value and the quality of sustainability reporting in Australia. Australian Accounting Review, 23(1), 67-87.

Bear, S., Rahman, N., \& Post, C. (2010). The impact of board diversity and gender composition on corporate social responsibility and firm reputation. Journal of Business Ethics, 97, 207-221.

Belal, A. R. (2002). Stakeholder accountability or stakeholder management: a review of UK firms' social and ethical accounting, auditing and reporting (SEAAR) practices. Corporate Social Responsibility and Environmental Management, 9(1), 8-25.

Belal, A. R., \& Cooper, S. (2011). The absence of corporate social responsibility reporting in Bangladesh. Critical Perspectives on Accounting, 22(7), 654-667.

Ben-Amar, W., Chang, M., \& McIlkenny, P. (2017). Board gender diversity and corporate response to sustainability initiatives: evidence from the carbon disclosure project. Journal of Business Ethics, 142, 369-383.

Berthelot, S., Coulmont, M., \& Serret, V. (2012). Do investors value sustainability reports? A Canadian study. Corporate Social Responsibility and Environmental Management, 19(6), 355-363.

Brammer, S., \& Pavelin, S. (2006). Voluntary environmental disclosures by large UK companies. Journal of Business Finance \& Accounting, 33(7-8), 1168-1188.

Branco, M. C., Delgado, C., Gomes, S. F., \& Eugénio, T. C. P. (2014). Factors influencing the assurance of sustainability reports in the context of the economic crisis in Portugal. Managerial Auditing Journal, 29 (3), 237-252.

Brown, D. L., Guidry, R. P., \& Patten, D. M. (2009a). Sustainability reporting and perceptions of corporate reputation: an analysis using fortune. Advances in Environmental Accounting \& Management, 4, 83-104.

Brown, H. S., De Jong, M., \& Levy, D. L. (2009b). Building institutions based on information disclosure: lessons from GRI's sustainability reporting. Journal of Cleaner Production, 17(6), 571-580.

Calabrese, A., Costa, R., \& Rosati, F. (2015). A feedback-based model for CSR assessment and materiality analysis. Accounting Forum, 39(4), 312-327.

Chau, G., \& Gray, S. J. (2010). Family ownership, board independence and voluntary disclosure: evidence from Hong Kong. Journal of International Accounting, Auditing and Taxation, 19(2), 93-109.

Clark, G. L., Feiner, A., \& Viehs, M. (2015). From the stockholder to the stakeholder: how sustainability can drive financial outperformance. Available at SSRN 2508281.

Clarkson, P. M., Li, Y., Richardson, G. D., \& Vasvari, F. P. (2008). Revisiting the relation between environmental performance and environmental disclosure: an empirical analysis. Accounting, Organizations and Society, 33(4-5), 303-327.

Clarkson, P. M., Overell, M. B., \& Chapple, L. (2011). Environmental reporting and its relation to corporate environmental performance. Abacus, 47(1), 27-60.

Cohen, J. R., Holder-Webb, L. L., Nath, L., \& Wood, D. (2012). Corporate reporting of nonfinancial leading indicators of economic performance and sustainability. Accounting Horizons, 26(1), 65-90.

Cormier, D., \& Magnan, M. (2003). Environmental reporting management: a continental European perspective. Journal of Accounting and Public Policy, 22(1), 43-62.

Cormier, D., Magnan, M., \& Van Velthoven, B. (2005). Environmental disclosure quality in large German companies: economic incentives, public pressures or institutional conditions? European Accounting Review, 14(1), 3-39.

Da Silva Monteiro, S. M., \& Aibar-Guzmán, B. (2010). Determinants of environmental disclosure in the annual reports of large companies operating in Portugal. Corporate Social Responsibility and Environmental Management, 17(4), 185-204.

Das, S., Dixon, R., \& Michael, A. (2015). Corporate social responsibility reporting: a longitudinal study of listed banking companies in Bangladesh. World Review of Business Research, 5(1).

De Beelde, I., \& Tuybens, S. (2015). Enhancing the credibility of reporting on corporate social responsibility in Europe. Business Strategy and the Environment, 24(3), 190-216.

Deegan, C. (2002). Introduction: the legitimising effect of social and environmental disclosures theoretical foundation. Accounting, Auditing \& Accountability Journal, 15(3), 282-311.

Dissanayake, D., Tilt, C., \& Qian, W. (2019). Factors influencing sustainability reporting by Sri Lankan companies. Pacific Accounting Review, 31(1), 84-109.

Eberhardt-Toth, E. (2017). Who should be on a board corporate social responsibility committee? Journal of Cleaner Production, 140, 1926-1935.

Fernando, A. A. J., \& Pandey, I. M. (2012). Corporate social responsibility reporting: a survey of listed Sri Lankan companies. Journal for International Business and Entrepreneurship Development, 6(2), 172-187. 
Fernando, S., Lawrence, S., Kelly, M., \& Arunachalam, M. (2015). CSR practices in Sri Lanka: an exploratory analysis. Social Responsibility Journal, 11(4), 868-892.

Fortanier, F., Kolk, A., \& Pinkse, J. (2011). Harmonization in CSR reporting MNEs and global CSR standards. Management International Review, 51(5), 665-696.

Fracarolli Nunes, M., \& Lee Park, C. (2017). Self-claimed sustainability: building social and environmental reputations with words. Sustainable Production and Consumption, 11, 46-57.

Freeman, R. E. (1994). The politics of stakeholder theory: some future directions. Business Ethics Quarterly, 4 (4), 409-421.

Gallo, P. J., \& Christensen, L. J. (2011). Firm size matters: an empirical investigation of organizational size and ownership on sustainability-related behaviors. Business \& Society, 50(2), 315-349.

Gamerschlag, R., Möller, K., \& Verbeeten, F. (2011). Determinants of voluntary CSR disclosure: empirical evidence from Germany. Review of Managerial Science, 5(2-3), 233-262.

Global Reporting Initiative. (2013). An introduction to G4: the next generation of sustainability reporting. Retrieved July, 25, 2014.

Global Reporting Initiative. (2018). Business reporting on the SDGs. Available at: https://www. globalreporting.org/information/SDGs/Pages/Reporting-on-the-SDGs.aspx [22 April 2020].

Guidry, R. P., \& Patten, D. M. (2010). Market reactions to the first-time issuance of corporate sustainability reports. Sustainability Accounting, Management and Policy Journal, 1(1), 33-50.

Haddock, J. (2005). Consumer influence on internet-based corporate communication of environmental activities: the UK food sector. British Food Journal. 107(10), 792-805.

Haddock-Fraser, J., \& Fraser, I. (2008). Assessing corporate environmental reporting motivations: differences between 'close-to-market' and 'business-to-business' companies. Corporate Social Responsibility and Environmental Management, 15(3), 140-155.

Hahn, R., \& Kühnen, M. (2013). Determinants of sustainability reporting: a review of results, trends, theory, and opportunities in an expanding field of research. Journal of Cleaner Production, 59, 5-21.

Haniffa, R. M., \& Cooke, T. E. (2005). The impact of culture and governance on corporate social reporting. Journal of Accounting and Public Policy, 24(5), 391-430.

Herzig, C., \& Schaltegger, S. (2006). Corporate sustainability reporting: an overview. In S. Schaltegger, M. Bennett, \& R. L. Burritt (Eds.), Sustainability accounting and reporting (pp. 301-324). Dordrecht: Springer.

Htay, S. N. N., Rashid, H. M. A., Adnan, M. A., \& Meera, A. K. M. (2012). Impact of corporate governance on social and environmental information disclosure of Malaysian listed banks: panel data analysis. Asian Journal of Finance \& Accounting, 4(1), 1-24.

Janggu, T., Joseph, C., \& Madi, N. (2007). The current state of corporate social responsibility among industrial companies in Malaysia. Social Responsibility Journal, 3(3), 9-18.

Jizi, M. (2017). The influence of board composition on sustainable development disclosure. Business Strategy and the Environment, 26(5), 640-655.

Jizi, M. I., Salama, A., Dixon, R., \& Stratling, R. (2014). Corporate governance and corporate social responsibility disclosure: evidence from the US banking sector. Journal of Business Ethics, 125(4), $601-615$.

Junior, R. M., Best, P. J., \& Cotter, J. (2014). Sustainability reporting and assurance: a historical analysis on a world-wide phenomenon. Journal of Business Ethics, 120(1), 1-11.

Kent, P., \& Monem, R. (2008). What drives TBL reporting: good governance or threat to legitimacy? Australian Accounting Review, 18(4), 297-309.

Khan, H. U. Z. (2010). The effect of corporate governance elements on corporate social responsibility (CSR) reporting: empirical evidence from private commercial banks of Bangladesh. International Journal of Law and Management, 52(2), 82-109.

Khlif, H., Guidara, A., \& Souissi, M. (2015). Corporate social and environmental disclosure and corporate performance. Journal of Accounting in Emerging Economies, 5(1), 51-69.

Kiliç, M., \& Uyar, A. (2014). The impact of corporate characteristics on social responsibility and environmental disclosures in Turkish listed companies. In Corporate Governance (pp. 253-276). Springer, Berlin.

Kiliç, M., Kuzey, C., \& Uyar, A. (2015). The impact of ownership and board structure on corporate social responsibility (CSR) reporting in the Turkish banking industry. Corporate Governance: The International Journal of Business in Society, 15(3), 357-374.

Klettner, A., Clarke, T., \& Boersma, M. (2014). The governance of corporate sustainability: empirical insights into the development, leadership and implementation of responsible business strategy. Journal of Business Ethics, 122(1), 145-165.

Kolk, A., \& Perego, P. (2010). Determinants of the adoption of sustainability assurance statements: an international investigation. Business Strategy and the Environment, 19(3), 182-198. 
KPMG. (2017). The road ahead. The KPMG Survey of Corporate Responsibility Reporting 2017.

Kuzey, C., \& Uyar, A. (2017). Determinants of sustainability reporting and its impact on firm value: evidence from the emerging market of Turkey. Journal of Cleaner Production, 143, 27-39.

Liao, L., Luo, L., \& Tang, Q. (2015). Gender diversity, board independence, environmental committee and greenhouse gas disclosure. The British Accounting Review, 47(4), 409-424.

Lo, S. F., \& Sheu, H. J. (2007). Is corporate sustainability a strategy for business? Corporate Governance: An International Review, 15(2), 345-358.

Lourenço, I. C., \& Branco, M. C. (2013). Determinants of corporate sustainability performance in emerging markets: the Brazilian case. Journal of Cleaner Production, 57, 134-141.

Lückerath-Rovers, M. (2013). Women on boards and firm performance. Journal of Management \& Governance, 17(2), 491-509.

Martínez, J. B., Fernández, M. L., \& Fernández, P. M. R. (2016). Corporate social responsibility: evolution through institutional and stakeholder perspectives. European Journal of Management and Business Economics, 25(1), 8-14.

Michelon, G., \& Parbonetti, A. (2012). The effect of corporate governance on sustainability disclosure. Journal of management \& governance, 16(3), 477-509.

Milne, M. J., \& Gray, R. (2013). W(h)ither ecology? The triple bottom line, the global reporting initiative, and corporate sustainability reporting. Journal of Business Ethics, 118(1), 13-29.

Moldavska, A., \& Welo, T. (2019). A holistic approach to corporate sustainability assessment: incorporating sustainable development goals into sustainable manufacturing performance evaluation. Journal of Manufacturing Systems, 50, 53-68.

Morioka, S. N., Bolis, I., Evans, S., \& Carvalho, M. M. (2017). Transforming sustainability challenges into competitive advantage: multiple case studies kaleidoscope converging into sustainable business models. Journal of Cleaner Production, 167, 723-738.

Moroney, R., Windsor, C., \& Aw, Y. T. (2012). Evidence of assurance enhancing the quality of voluntary environmental disclosures: an empirical analysis. Accounting \& Finance, 52(3), 903-939.

Nobanee, H., \& Ellili, N. (2016). Corporate sustainability disclosure in annual reports: evidence from UAE banks: Islamic versus conventional. Renewable and Sustainable Energy Reviews., 55, 1336-1341.

Nor, N. M., Bahari, N. A. S., Adnan, N. A., Kamal, S. M. Q. A. S., \& Ali, I. M. (2016). The effects of environmental disclosure on financial performance in Malaysia. Procedia Economics and Finance, 35, $117-126$.

Odoemelam, N., \& Ofoegbu, G. (2018). Corporate board characteristics and environmental disclosure quantity: a comparative analysis of traditional and integrated reporting evidence.

Ofoegbu, G. N., Odoemelam, N., \& Okafor, R. G. (2018). Corporate board characteristics and environmental disclosure quantity: evidence from South Africa (integrated reporting) and Nigeria (traditional reporting). Cogent Business \& Management, 5(1), 1-27.

Ortas, E., Álvarez, I., \& Zubeltzu, E. (2017). Firms' board independence and corporate social performance: a meta-analysis. Sustainability, 9(6), 1006.

Osazuwa, N. P., Che-Ahmad, A., \& Che-Adam, N. (2016). Board characteristics and environmental disclosure in Nigeria. Information (Japan), 19(18A), 3069-3074.

Othman, R., \& Ameer, R. (2009). Corporate social and environmental reporting: where are we heading? A survey of the literature. International Journal of Disclosure and Governance, 6(4), 298-320.

Park, J., \& Brorson, T. (2005). Experiences of and views on third-party assurance of corporate environmental and sustainability reports. Journal of Cleaner Production, 13(10-11), 1095-1106.

Peters, G. F., \& Romi, A. M. (2015). The association between sustainability governance characteristics and the assurance of corporate sustainability reports. Auditing: A Journal of Practice \& Theory, 34(1), 163-198.

Pflugrath, G., Roebuck, P., \& Simnett, R. (2011). Impact of assurance and assurer's professional affiliation on financial analysts' assessment of credibility of corporate social responsibility information. Auditing: A Journal of Practice \& Theory, 30(3), 239-254.

Post, C., Rahman, N., \& Rubow, E. (2011). Green governance: boards of directors' composition and environmental corporate social responsibility. Business \& Society, 50(1), 189-223.

Raman, A. A., \& Bukair, A. A. (2013). The influence of the Shariah supervision board on corporate social responsibility disclosure by Islamic banks of gulf co-operation council countries. AJBA, $6(2)$.

Rao, K. K., Tilt, C. A., \& Lester, L. H. (2012). Corporate governance and environmental reporting: an Australian study. Corporate Governance: The International Journal of Business in Society, 12(2), 143163.

Reverte, C. (2009). Determinants of corporate social responsibility disclosure ratings by Spanish listed firms. Journal of Business Ethics, 88(2), 351-366. 
Rosati, F., \& Faria, L. G. D. (2019). Business contribution to the sustainable development agenda: organizational factors related to early adoption of SDG reporting. Corporate Social Responsibility and Environmental Management, 26(3), 588-597.

Sarbah, A., \& Xiao, W. (2015). Good corporate governance structures: a must for family businesses. Open Journal of Business and Management, 3(01), 40-57.

Schadewitz, H., \& Niskala, M. (2010). Communication via responsibility reporting and its effect on firm value in Finland. Corporate Social Responsibility and Environmental Management, 17(2), 96-106.

Scherer, A. G., Palazzo, G., \& Seidl, D. (2013). Managing legitimacy in complex and heterogeneous environments: sustainable development in a globalized world. Journal of Management Studies, 50(2), 259-284.

Schreck, P., \& Raithel, S. (2018). Corporate social performance, firm size, and organizational visibility: distinct and joint effects on voluntary sustainability reporting. Business \& Society, 57(4), 742-778.

Setó-Pamies, D. (2015). The relationship between women directors and corporate social responsibility. Corporate Social Responsibility and Environmental Management, 22(6), 334-345.

Shamil, M. M., Shaikh, J. M., Ho, P. L., \& Krishnan, A. (2014). The influence of board characteristics on sustainability reporting: empirical evidence from Sri Lankan firms. Asian Review of Accounting, 22(2), 78-97.

Sharif, M., \& Rashid, K. (2014). Corporate governance and corporate social responsibility (CSR) reporting: an empirical evidence from commercial banks (CB) of Pakistan. Quality \& Quantity, 48(5), 2501-2521.

Sierra, L., Zorio, A., \& García-Benau, M. A. (2013). Sustainable development and assurance of corporate social responsibility reports published by Ibex-35 companies. Corporate Social Responsibility and Environmental Management, 20(6), 359-370.

Siregar, S. V., \& Bachtiar, Y. (2010). Corporate social reporting: empirical evidence from Indonesia stock exchange. International Journal of Islamic and Middle Eastern Finance and Management.

Stanny, E., \& Ely, K. (2008). Corporate environmental disclosures about the effects of climate change. Corporate Social Responsibility and Environmental Management, 15(6), 338-348.

Tagesson, T., Blank, V., Broberg, P., \& Collin, S. O. (2009). What explains the extent and content of social and environmental disclosures on corporate websites: a study of social and environmental reporting in Swedish listed corporations. Corporate Social Responsibility and Environmental Management, 16(6), $352-364$.

Trireksani, T., \& Djajadikerta, H. G. (2016). Corporate governance and environmental disclosure in the Indonesian mining industry. Australasian Accounting, Business and Finance Journal, 10(1), 18-28.

United Nations General Assembly. (2015). Transforming our world: the 2030 agenda for sustainable development. New York. Available at: https://sustainabledevelopment.un.org/post2015/ transformingourworld [05 April 2020].

Uwuigbe, U., Teddy, O., Uwuigbe, O. R., Emmanuel, O., Asiriuwa, O., Eyitomi, G. A., \& Taiwo, O. S. (2018). Sustainability reporting and firm performance: a bi-directional approach. Academy of Strategic Management Journal, 17(3), 1-16.

Zhang, L. (2012). Board demographic diversity, independence, and corporate social performance. Corporate Governance: The International Journal of Business in Society, 12(5), 686-700.

Publisher's Note Springer Nature remains neutral with regard to jurisdictional claims in published maps and institutional affiliations.

\section{Affiliations}

\section{Alicia Girón ${ }^{1} \cdot$ Amirreza Kazemikhasragh $^{1} \cdot$ Antonella Francesca Cicchiello $^{2} \cdot$ Eva Panetti ${ }^{3}$}

1 University Program of Studies on Asia and Africa (PUEAA), National Autonomous University of Mexico (UNAM), Mexico City, Mexico

2 Dipartimento di Scienze Economiche e Sociali, Università Cattolica del Sacro Cuore, Piacenza, Italy

3 Dipartimento di Studi Aziendali e Quantitativi, Università degli Studi di Napoli Parthenope, Naples, Italy 